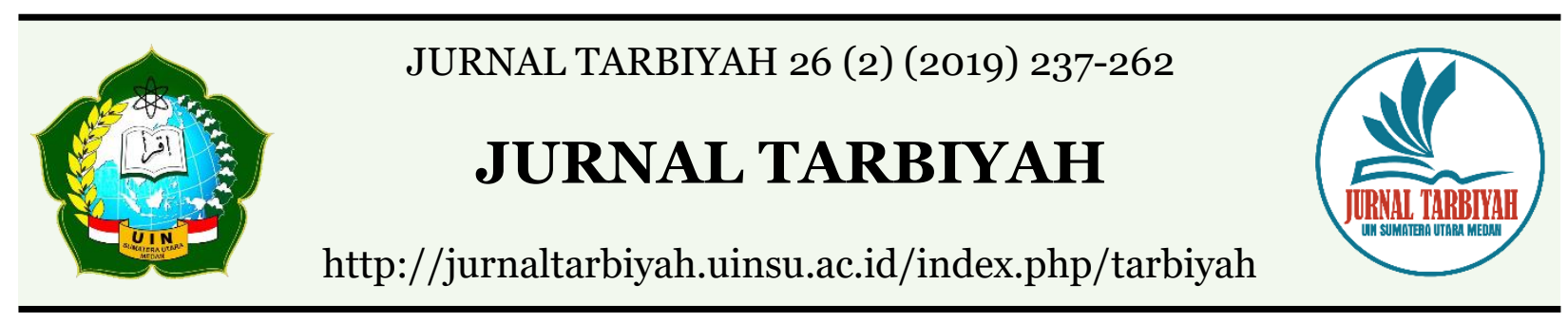

\title{
DEVELOPING THE DESIGN OF CHARACTER EDUCATION THROUGH INTEGRATED CURRICULUM IN STATE ISLAMIC UNIVERSITY OF NORTH SUMATRA MEDAN
}

\author{
Mardianto', Irwan S2, Fauziah Nasution3 \\ 1,2,3 Universitas Islam Negeri Sumatera Utara, Medan, Indonesia \\ Email: mardianto@uinsu.ac.id
}

DOI : 10.30829/tar.v26i2.483

Accepted: August 29th, 2019. Approved: December 18th, 2019. Published: December 25th, 2019

\begin{abstract}
This study aims to develop the design of character education through an integrated curriculum in learning activities at UIN of North Sumatra Medan. This research activity is expected to provide a direct contribution to learning activities at UIN of North Sumatra Medan. Specifically, the contribution of this research is expected to contribute to: (1) the lecturers in developing learning that is able to develop and educate student characters, (2) the students of UIN of North Sumatra Medan to have the character as expected by UIN of North Sumatra Medan curriculum, and (3) UIN of North Sumatra Medan in developing character-based learning program design. When character education is taught with an integrated approach in the curriculum, it is a strategic concept to strengthen the values of goodness for the students. This certainly requires a design that can be developed in learning activities for the classroom and implemented by lecturers to students.
\end{abstract}

Keywords: Integration into the curriculum, learning design, student character, portfolio. 
Mardianto, Irwan S, Fauziah Nasution / JURNAL TARBIYAH 26 (2) (2019) 237-262

\section{INTRODUCTION}

Indonesia towards the year 2045 has great hopes of experiencing a golden generation, in which 100 years of Indonesia's independence day, Indonesia is achieving the dream of independence as aspired by the patriots. For this reason, various preparations have been made, government regulations related to education have been carried out since the Law No.20 of 2003 of the Republic of Indonesia on the National Education System, Law No.14 of 2005 concerning Teachers and Lecturers and various other derivative regulations. One of the efforts to produce a golden generation is by teaching character education, which is expected to provide a strong foundation about the figure of the golden generation. Thus, a character education needs to be formulated, developed and carried out in a sustainable manner, both by the government and the community especially by educational institutions. From here on, the government is currently promoting what is called the Nation Culture and Character education.

UIN of North Sumatra Medan has a vision of building a learning community based on Islamic values. For this reason, the aim of UIN of North Sumatra Medan is to prepare students to become Muslim scholars who possess noble character, strong academic and professional skills and skills in Islamic science; to be used in further education and interacting in the social, cultural, and natural environment in social life towards learning communities (UIN of North Sumatra Medan Statute, 2016).

This research problem departs from an expectation that ideally character education has been well implemented in learning activities in the classes at UIN of North Sumatra Medan. However, in reality, a learning process in the classroom has not been integrated into the curriculum at UIN of North Sumatra Medan. Understanding this condition, the class is not a problem that stands alone, in which as a system, curriculum development at the university level must be seen in totality. In turn, the class problem raises the problem that there are problems in developing character learning in curriculum integration at UIN of North Sumatra Medan. The formulation of this study is: How to develop character education design in an integrated curriculum in UIN of North Sumatra Medan environment?

This study aims to develop the character education design through an integrated curriculum in learning activities at UIN of North Sumatra Medan. This research activity is expected to provide a direct contribution to learning activities at UIN of North Sumatra Medan. Specifically, the contribution of this research is expected to contribute to: (1) lecturers in developing learning that is able to develop and educate student characters, 
Mardianto, Irwan S, Fauziah Nasution / JURNAL TARBIYAH 26 (2) (2019) 237-262

(2) students of UIN of North Sumatra Medan to have the character as expected by the UIN of North Sumatra Medan curriculum, and (3) UIN of North Sumatra Medan in developing character-based learning program designs.

\section{LITERATURE REVIEW}

\section{Knowing Character Education}

Education is the process of transforming cultural values from one generation to the next. One of the transformed values is character, where the instilled values are grown and developed for students including students at a tertiary institution. In Islamic studies, character education is very important. Marzuki (2017: 38) explains that character education is the main mission of Islamic education and the realization of character among the people cannot be separated from the process of Islamic education. If Islamic education is carried out properly and successfully in accordance with its objectives, Muslims will become human beings with character. Meanwhile Syaiful Sagala (2013: 231) asserted that building an education with noble character and intelligent through educational activities will form the students with high nationalism and nationalism spirit, and can participate in advancing world civilization. The learning process that instills and places the rules of character and intelligence in high levels will be like a tower soaring upward and consistent.

Planning a character education program is not easy, but requires a variety of thoughts, commitment to the good cooperation between various parties. In this case, Thomas Lickona (2016: 295) identified at least twenty general components in quality character education. Thus, cold character is built through character education that is inside-out, it means that this behavior that develops into good habits occurs because of impulses from within, not because of coercion from outside.

The Ministry of National Education also pays special attention to character building for students. In the guide book (2010) compiled for the activities of developing cultural education and national character explained that; The learning process of Nation Culture and Character Education is carried out through an active learning process. In accordance with the principle of value development, it must be done actively by students (the students are the subject who will receive, make values as their own and make the values they have learned as the basis in every action) then the position of students as active subjects in learning is the main principle of active learning. Therefore, both of them need each other. 
Abdullah Nashih Ulwan (1981: 141) explains that there are five learning strategies that build character: (1) role models, (2) habits, (3) advice, (4) giving attention, and (5) giving punishment. How important is character education, the implementation strategy must be arranged in such a way, it even requires a special strategy. Zubaedi (2011: 198) in this case emphasizes that the strategy of developing macro characteristics can be carried out through three stages, namely; the first, the planning stage, the second implementation phase, and the third evaluation phase. The strategies for developing character education will be even better if it is carried out by integrating into the curriculum. As explained by Ruseno Arjanggi (2012) that integrated education is the right way to overcome various national problems, through integrating character education into teaching and learning. The offered solution is through active and caring learning methods such as cooperative learning.

From the Islamic perspective, character development is always developed with the moral education initiative where the Prophet Muhammad becomes a prime example of character. Abdul Madjid and Dian Andayani (2017: 112-113) assert that there are three strategies that must be passed for character education towards the formation of noble morals, namely as follows: (a) Moral Knowing / Learning to know is the stage where the first step in character education is to master knowledge about values. (b) Moral Loving / Moral Feeling is the stage where learning to love without conditions. (c) Moral Doing / Learning to do is the stage in which students practice character in everyday life.

Character building is not something that can be done instantly, but it requires a process. In the national curriculum; it is different from teaching material that is mastered, as in the case of a ' performance content of a competency, the material for Culture and National Education is 'developmental '. The differences in the nature of the two groups of material require different treatment in the educational process. Educational material that is 'developmental' requires a fairly long educational process and is mutually reinforcing between learning activities with other learning activities. Thus character education when done with an integrated approach in the curriculum is a strategic concept to strengthen the values of goodness for the students. This certainly requires a design that can be developed in learning activities for the classroom and implemented by lecturers to students. 
Mardianto, Irwan S, Fauziah Nasution / JURNAL TARBIYAH 26 (2) (2019) 237-262

\section{Character Education for Students}

Education is the process of transforming cultural values from one generation to the next. One of the transformed values is character, where the values instilled are grown and developed for students including students at a tertiary institution. Siti Irene Astuti (2010), Ministry of National Education (2010) until Abdullah Nashih Ulwan (1981) explained that there are five learning strategies that build character: (1) role models, (2) habits, (3) advice, (4) giving attention, and (5) giving punishment. How important is character education, the implementation strategy must be arranged in such a way, it even requires a special strategy. Zubaedi (2011) in this case emphasized that the strategy for developing macro characters can be carried out through three stages, namely; first, the planning stage, the second implementation phase, and the third evaluation phase. Strategies for developing character education will be even better if carried out by integrating into the curriculum. As explained by Ruseno Arjanggi (2012) that integrated education is the right way to overcome various national problems, through integrating character education into teaching and learning. The solution offered is through active and caring learning methods such as cooperative learning.

\section{Millennial Generation}

Today's millennial-based digital application is now a major issue in various lines. In recent years the definition of generation has evolved, one of which is the definition according to Kupperschmidt's (2000) who says that a generation is a group of individuals who identify their groups based on similarity in birth years, age, location, and events in the lives of these groups of individuals who have significant influence in their growth phase. One of the definitions is the theory of the differences in generation of popularity popularized by Neil Howe and William Strauss in 1991. Howe \& Strauss (1991, 2000) divide generations based on the similarity of birth spans and the similarity of historical events. The division of generations was also expressed by many other researchers with different labels - but generally have the same meaning. For example, according to Martin \& Tulgan (2002) Generation $Y$ is the generation born in the range of 1978, while according to Howe \& Strauss (2000) generation $Y$ is the generation born in 1982, this is due to the different schemes used to classify generations. This is because the researchers are from different countries.

Some research results have consistently compared differences in generations, with samples ranging from the 1950 s to early 2000 , showing differences in the characteristics 
of the 3 generation groups, namely baby boomers, generation $\mathrm{X}$ and generation $\mathrm{Y}$ (Millennial). On the other hand; they look very reactive to the environmental changes that occur around them, have more attention to wealth.

Millennial generation 1 has the following characteristics: Studies on the millennial generation, especially in America, have been carried out, including studies conducted by Boston Consulting Group (BCG) with the University of Berkley in 2011 with the theme of American Millennials: Deciphering the Enigma Generation. The previous year, 2010, the Pew Research Center also released a research report titled Millennials: A Portrait of Next Generation. Based on the research, this is the characteristic of the millennial generation; (1) First, Millennial trusts User Generated Content (UGC) more than direct information. (2) Second, Millennial prefers cell phones to TVs. (3) Third, Millennials must have social media. (4) Fourth, Millennials do not like to read conventionally. (5) Fifth, Millennials know more about technology than their parents. (6) Sixth, Millennials tend to be disloyal, but work effectively. (7) Seventh, Millennial began a lot of cashless transactions.

\section{The Need to Safeguard Generation Coaching}

The younger generation as the next generation and the hope of the nation, requires fostering a firm aqidah tauhid (monotheistic faith), the formation of sound reasoning and noble character, in order to be able to face increasingly severe challenges in navigating this life, apart from the stagnation of the mindset and the backwardness of some older and younger generations itself. The success of coaching the younger generation is influenced and determined by the relevance and mutual support between coaching in the household with education in schools and the values adopted and developed in the community. Educators in a broad sense must avoid contradictions between norms developed in educational institutions with values in the family and community, so students do not experience confusion to choose which of them is right or must be followed.

Therefore, moral life cannot be separated from religious beliefs, because moral values that are firm, certain and permanent, do not change because of circumstances, place and time, are values that originate from religion. Therefore, in fostering the younger generation, the moral and religious life needs to be in line and receive serious attention. 
Mardianto, Irwan S, Fauziah Nasution / JURNAL TARBIYAH 26 (2) (2019) 237-262

\section{The Role of Educational Development}

Students in the millennial era have an attitude of dependence on social media, while they do not have a strong filter yet to be able to sort and select the information they receive. Therefore educational institutions in the millennium region need to prepare themselves by improving their attitudes and competencies, so that they become figures that inspire their students.

Whereas through the field of student affairs, it has a vision to shape students into pious, moral, intelligent, critical, polite, democratic, responsible, cultured and highly competitive individuals. Based on these character values, the missions of student affairs are: (1) improving the quality of faith, devotion and morals of students, (2) developing students' intellectual capabilities, (3) developing students to think critically, politely, morally, and cultured based on the rule of law and academic norms, (4) instilling a constructive sense of student nationalism as Indonesian citizens in the Unitary State of the Republic of Indonesia, (5) fostering creativity and student entrepreneurial spirit to enhance the nation's competitiveness, (6) developing idealism and a democratic atmosphere in life student affairs, (7) improving the quality of student leadership, (8) improving the quality of student organizations by oriented to professionalism.

There are a number of noble character values that can be extracted from the treasury to build the character of the millennial generation. Character education, according to EkoHandoyo (2010) recommends that noble character values that have developed so far and can be further developed, including religious values, honesty, caring, tolerant, democratic, polite, intelligent, and tough.

\section{Development of Learning Designs}

Development of learning design begins with the development of learning models. Some learning models that are known so far are the Dick and Carey model. In general, the development of learning models according to Trianto (2014: 221) consists of several stages, namely, first defining, second designing, third developing and fourth spreading. And the design of learning or design for learning among students, then; build mutual understanding the policies and procedures of lectures are important for class cohesiveness. This means that to build values in students must begin with how to design learning from the classroom.

Learning designs that can be integrated with the curriculum, especially for face-toface lectures can be seen in various other design models including, David Marrill, Jerold 
E. Kemp (1985) that at the very least, design must be able to answer four important elements, namely for whom the program is designed, what abilities will be desired after learning, how the content of the lesson is developed and what skills must be mastered, and finally how do we know the success of the activities that have been carried out Regeluth (1983) limits that instructional design is this thinking science-a body of knowledge that prescribes instructional actions to optimize desired instruction outcomes, such as achievement and affect.

\section{RESEARCH METHOD}

\section{Research Design and Procedures}

The design of this research is the development-based research design or model development. Developmental research for learning design activities can be borrowed from Borg \& Gall (2003). According to him there are at least six main steps in this developmental research, namely; (1) formulating objectives, (2) reviewing the situation and identify approaches, (3) developing new products or designs, (4) testing products, (5) revising them until they are successful, and (6) implementing them. The steps as above, are used as a guide in developing designs for the preparation, development, revision to reporting.

As a developmental research, this study uses descriptive analysis with qualitative analysis, aimed at describing the conditions of character development and developing an integrated character learning design in the curriculum in UIN of North Sumatra Medan. Describing the conditions means to see what is happening among the students, lecturers, curriculum and systems related to character development in UIN of North Sumatra Medan. Likewise, finding a solution is to find a solution that is expected to be made an offer or choice regarding character development.

Meanwhile the procedure of this research is to use a flowchart of the conditions regarding character development among students, analyzed, then developed an alternative learning design. Considerations using this analysis are; firstly is knowing the character education characteristics in depth so far, secondly exploring various theories and studies related to character education for students, and thirdly developing a character education design that can be integrated into the curriculum in UIN of North Sumatra Medan. The following charts are shown in the research flowchart as follows: 
Mardianto, Irwan S, Fauziah Nasution / JURNAL TARBIYAH 26 (2) (2019) 237-262

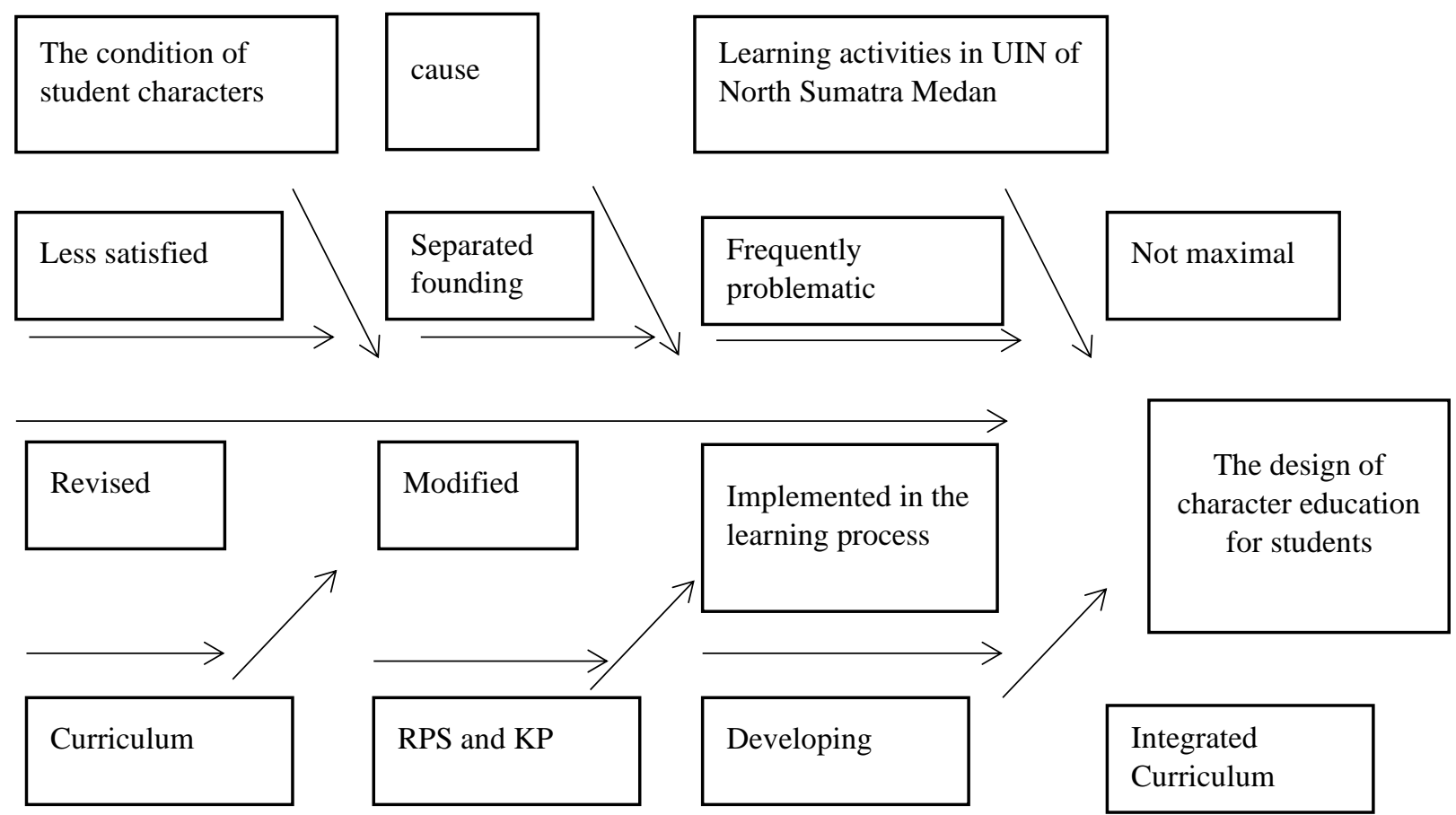

The research flowchart (fishbone diagram) above illustrates that so far the condition of the character learning at UIN North Sumatra Medan has not been systematically programmed, focused and indicated. Therefore, the researcher wants to improve the design of character education which is expected to be able to be carried out effectively by involving lecturers and students. The design of model development in this research is as follows:

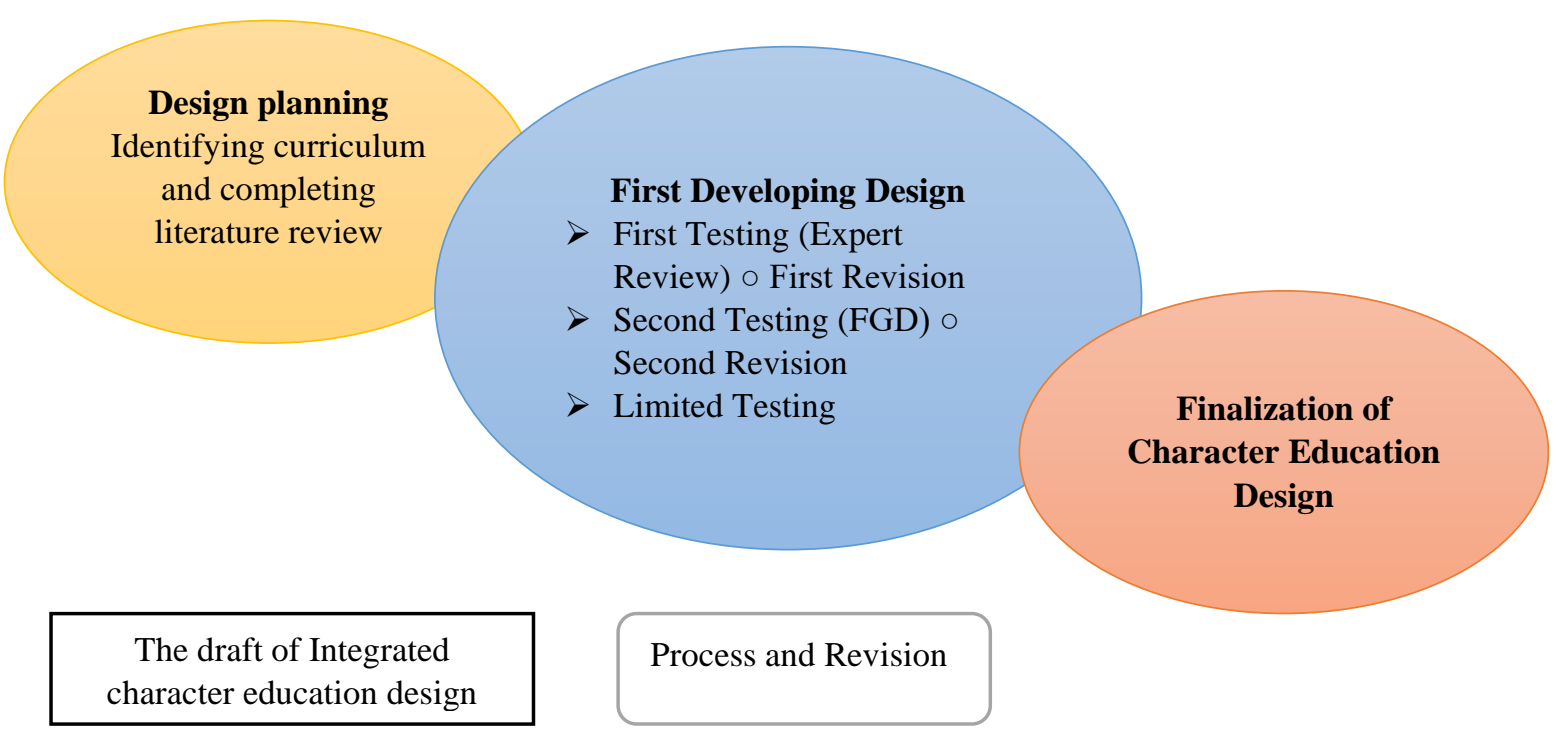

Figure 1 Steps of Model Development Research 
Mardianto, Irwan S, Fauziah Nasution / JURNAL TARBIYAH 26 (2) (2019) 237-262

\section{Data Collection Techniques}

Literature study, namely by studying and collecting data, various references (literature) and reading sources that support research. Researchers believe that the literature is very important in a study. The availability of literature by considering the relevance of the concepts used in strengthening theories in explaining various research phenomena.

A field study that is conducting intensive document study activities, meaning that it is carried out in various ways to obtain data, facts about learning in the UIN of North Sumatra Medan. Data recording and field facts aim to get a more realistic picture of learning, or character development that has been done or not done by lecturers.

The interview is an activity to get qualitative opinions from key informants related to the design and description of character development that has occurred so far at UIN of North Sumatra Medan. Focus Group Discussion (FGD) with several resources determined to be key informants about character learning by the vice dean of academic and student affairs, heads of the departments, academic advisors, lecturers in class and students.

\section{Research Informants}

The informants of this study were the informants who were first made in character education activities, namely; lecturers, faculty leaders, especially the Vice Dean for academic and institutional collaboration, and the vice dean for Student Affairs and alumni, and a department head from the faculty, as well as two academic advisors, and 12 students. Specifically for design reviewers there were two experts from different fields, namely the field of learning design or educational technology as well as from the field of character education or moral education.

\section{Data Analysis Techniques}

This research was a qualitative research design or model development. The analysis is done by reducing the data, then developing and considering various inputs from informants and experts. Miles and Huberman (1984) have a good way to explain how triangulation works concretely in an investigation of a puzzle: "Detectives involve complicated instrumentation. When detectives amass fingerprints, hair samples, alibis, eyewitnesses and the like, cases that are built may fit on one or more allegations. Various types of measurements that provide repeated verification. " 
Mardianto, Irwan S, Fauziah Nasution / JURNAL TARBIYAH 26 (2) (2019) 237-262

Of the four types of triangulation presentations we have established one, namely; Multiple Researchers Triangulation. The involvement of several researchers is different in the analysis process. The concrete form is usually an evaluation team consisting of colleagues who master specific methods into a Focus Group Discussion (FGD). In this study, researchers are a team that has different backgrounds so the three are considered professionals to see the results of the data with different perspectives.

\section{Research Locations and Schedules}

This research was conducted in the UIN of North Sumatra Medan environment in learning the academic year 2017/2018 and 2018/2019. The research area environment covers two main campuses namely; a. UIN of North Sumatra campus on IAIN street number 1 Medan, and b. UIN of North Sumatra Campus Medan on the Willim Iskandar Deli Serdang Street, North Sumatra. While the research schedule is carried out for one year of the research budget which is in2018.

\section{FINDING AND DISCUSSION}

\section{Model Development Results}

The development of models for character education through an integrated curriculum is certainly based on regulations, institutions, theories and functions to achieve the goals of character development. There are at least three important parts that will be developed in this model namely; institutions namely the North Sumatra State Islamic University of Medan, Lecturers and Students, as well as the Process from the Curriculum to the Phase One Trial Portfolio

The model developed from the theoretical study above, then given to experts with the aim to get input, especially in developing character education design. This input is expected before this design is further developed as a model. Experimental review trials in this case are two experts who are considered to have the ability namely Prof. Haidar Daulay Professor of Islamic Education History and Dr. Siti Halimah, M.Pd who have competence in the curriculum, and have experienced their respective fields for more than ten years at the University. In this case the team received input from experts Prof.Dr. Haidar and Dr.Siti Halimah qualitatively which were then assembled into input components, input material and follow-up that had to be developed in the next design. About this can be seen in the following table: 
Mardianto, Irwan S, Fauziah Nasution / JURNAL TARBIYAH 26 (2) (2019) 237-262

Table 1 Suggestion and Follow up from Expert

\begin{tabular}{|c|c|c|c|}
\hline No & Component & Suggestion & Follow up \\
\hline \multirow[t]{2}{*}{1} & $\begin{array}{l}\text { Curriculum } \\
\text { Analysis }\end{array}$ & $\begin{array}{l}\text { Haidar } \\
\text { If UIN of North Sumatra Medan has a vision, } \\
\text { mission and goals, then the curriculum has been } \\
\text { given. }\end{array}$ & \multirow{2}{*}{$\begin{array}{l}\text { The identification of } \\
\text { the Vision, Mission } \\
\text { and objectives of UIN } \\
\text { of North Sumatra } \\
\text { should be used as a } \\
\text { reference for } \\
\text { curriculum } \\
\text { development }\end{array}$} \\
\hline & & $\begin{array}{l}\text { Siti Halimah } \\
\text { Curriculum for character can be developed from } \\
\text { various sides, extra or hidden curriculum for } \\
\text { character education. }\end{array}$ & \\
\hline \multirow[t]{2}{*}{2} & $\begin{array}{l}\text { Determination } \\
\text { of the } \\
\text { institution }\end{array}$ & $\begin{array}{l}\text { Haidar } \\
\text { Remember, the more institutions are, the more } \\
\text { increasingly ineffective for curriculum } \\
\text { development it is }\end{array}$ & \multirow{2}{*}{$\begin{array}{l}\text { The institution only } \\
\text { concerns those directly } \\
\text { related to character } \\
\text { education, namely; } \\
\text { LPM, Faculty } \\
\text { and Study Pogram. }\end{array}$} \\
\hline & & $\begin{array}{l}\text { Siti Halimah } \\
\text { From several institutions there must be } \\
\text { coordination, and communication is the main } \\
\text { thing. }\end{array}$ & \\
\hline \multirow[t]{2}{*}{3} & $\begin{array}{l}\text { Determination } \\
\text { of the } \\
\text { institution }\end{array}$ & $\begin{array}{l}\text { Haidar } \\
\text { The examples of role models from lecturers } \\
\text { are the main strategies. }\end{array}$ & \multirow{2}{*}{$\begin{array}{l}\text { Strategies used in } \\
\text { the field must make } \\
\text { the lecturers in the } \\
\text { class and academic } \\
\text { advisor as the } \\
\text { spearhead. }\end{array}$} \\
\hline & & $\begin{array}{l}\text { Siti Halimah } \\
\text { Many choices of strategies in learning, including } \\
\text { character building. }\end{array}$ & \\
\hline \multirow[t]{2}{*}{4} & $\begin{array}{l}\text { Character } \\
\text { selection }\end{array}$ & $\begin{array}{l}\text { Haidar } \\
\text { It must be remembered that the character } \\
\text { should be from the small things of student and } \\
\text { lecturer habits }\end{array}$ & \multirow{2}{*}{$\begin{array}{l}\text { The characters are } \\
\text { unearthed from } \\
\text { Islam, UIN of North } \\
\text { Sumatra Medan and } \\
\text { the current world of } \\
\text { students (millennial) }\end{array}$} \\
\hline & & $\begin{array}{l}\text { Siti Halimah } \\
\text { Character values must have references. }\end{array}$ & \\
\hline \multirow[t]{3}{*}{5} & $\begin{array}{l}\text { Instrument } \\
\text { selection }\end{array}$ & Haidar & $\begin{array}{l}\text { Portfolio instruments } \\
\text { are renewed or refined }\end{array}$ \\
\hline & & It is not only portfolio, there are others too. & \\
\hline & & $\begin{array}{l}\text { Siti Halimah } \\
\text { The portfolios, if it is maximized from the } \\
\text { beginning, it is the right choice }\end{array}$ & \\
\hline 6 & $\begin{array}{l}\text { Personal } \\
\text { selection }\end{array}$ & $\begin{array}{l}\text { Haidar } \\
\text { The spearhead of the character is another new }\end{array}$ & $\begin{array}{l}\text { Dosen Penasehat } \\
\text { Akademik, Dosen }\end{array}$ \\
\hline
\end{tabular}


Mardianto, Irwan S, Fauziah Nasution / JURNAL TARBIYAH 26 (2) (2019) 237-262

\begin{tabular}{|l|l|l|l|}
\hline & lecturer. & $\begin{array}{l}\text { di Kelas, Ketua } \\
\text { Prodi adalah } \\
\text { personalia penting. }\end{array}$ \\
\hline 7 & $\begin{array}{l}\text { Model } \\
\text { development }\end{array}$ & $\begin{array}{l}\text { The students need to be accompanied with } \\
\text { academic advisors, because the lecturers of the } \\
\text { courses are only known for one semester. }\end{array}$ & $\begin{array}{l}\text { Models can be developed from existing ones } \\
\text { and proved effective. }\end{array}$ \\
\hline $\begin{array}{l}\text { Siti Halimah } \\
\text { The model is a general description, it is not } \\
\text { necessarily detailed but can accommodate all the } \\
\text { available components }\end{array}$ & $\begin{array}{l}\text { The model will be } \\
\text { refined which is able } \\
\text { to guide the personal } \\
\text { character education }\end{array}$ \\
\hline
\end{tabular}

From the input provided, the research team held a meeting and then revised it to improve the next design model. This model is certainly based on a developing theory where the study continues to be carried out, adaptation of various inputs, especially two experts, and finally become a model prepared for further activities. The preparation of this model is very important because each stage can be used as a reference for evaluation and revision, and so on for the design of the development of this model to be perfect.

\section{Phase Two Model Testing}

The second phase of the trial was given during the Focus Group Discussion (FGD) forum. This forum is carried out to develop designs for users, namely students, academic advisors, chair of departments, as well as two speakers from outside the North Sumatra State Islamic University in Medan. FGDs are held in the form of forums, for one day to share, consult and mutually respond to one another. With this FGD, of course the components that are developed can achieve maximum results. This means that each component can be analyzed according to different views, user views, and finally the views of various recent studies.

From some of the above inputs, in the end the revision and development of the model for the stage three was carried out. Discussions with the research team and the collection of results from the field, showed that there needed to be some major revision to make improvements. In this case, the resulting design model is as follows: 


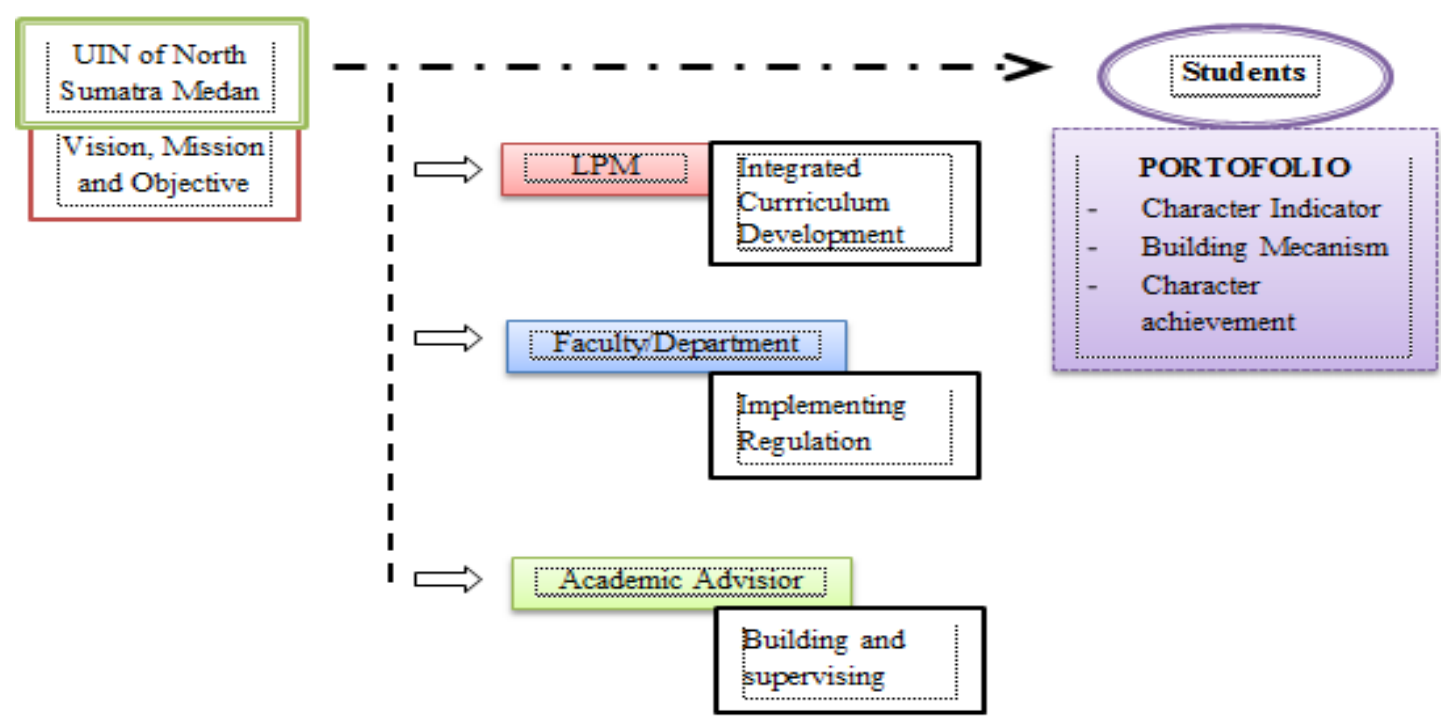

Figure 2. Third Design of Character Education Through Integrated Curriculum

\section{Phase Three Model Testing}

This trial is carried out by developing further details of each component. This trial is expected to provide more systematic signs, from the time of curriculum development, the development of character values to the development of portfolio instruments.

The overall development of this stage model is more evident in the development of portfolios, each with a value of 17 characters detailed on the basis of the Qur'an and Al Hadith, from the vision and mission of UIN of North Sumatra Medan, to the development of professional and public self. For this reason, the development of this third stage model is expected to be the final of a whole series of design developments that will result from this research.

\section{RESULTS OF CHARACTER EDUCATION DESIGN Student Character Education Design As A Model}

North Sumatra State Islamic University Medan, is a state Islamic tertiary institution in North Sumatra, located in the city of Medan. Now growing and developing, becoming part of government institutions that have a strategic role in building Indonesia's golden generation in 2045.

The vision of UIN of North Sumatra Medan, namely "making the Learner community based on Islamic values, is a very futuristic but also collaborative formula. 
Futuristic means having leadership that is very meaningful for efforts to build the Ummah in Indonesia that might be realized in 2045. While collaborative is to show that there is cooperation among the academic community, coaching, development of empowering all potential can be realized. The embodiment is for UIN of North Sumatra Medan to win in the middle of the Ummah both in Indonesia and the world community.

Faculty of faculties in UIN of North Sumatra Medan as a part of the institution, have several departments that function to foster and develop scientific disciplines to create reliable professionals. The department works closely with lecturers, academic advisors and student organizations at UIN of North Sumatra Medan is the concentration on the effort to create Islamic scholars ready with various challenges and hopes of the ummah about Islam in the future.

Towards UIN of North Sumatra Medan Champion, vision and mission developed through education and learning, students are empowered, developed, and fostered both academics, extra-curricularly, and in the community. For this reason, character building as one of the main pillars of the formation of personal campus residents, especially students, is expected to have the ability to build a reliable profession as well as the pillars of strength to build the Ummah through UIN of North Sumatra Medan Champion. It is important for UIN of North Sumatra Medan, through its faculties and departments to provide academic, practical, portfolio-based academic guidance, guidance and guidance in fostering student character.

\section{Character Education Design}

In the case of the development of character education design, the assumptions that are the basis of the curriculum guide UIN of North Sumatra Medan. In the curriculum, there is a vision, mission and goals that underlie the development of Tridharma activities, namely learning education, research and community service. As a system, this design is developed in the form of a model development pattern, meaning that the integration is binding between universities, faculties, lecturers to students are with integrated curriculum development. So, since from UPM, the departments, until lecturers and students have the same work pattern, and achieve the same goals.

Models like this are then used as the basis for design development that can be offered for development. Model visualization is certainly the result of trials developed in various activities both from policy studies, theoretical studies, field studies, and finally 
the resulting model is offered in a guidebook. For more clearly and in detail the development of this model, it can be seen in the pages.

\section{Development Mechanism for Student Character Development}

The implementation of student character development is a comprehensive program effort carried out with planning, management, and evaluation to be accountable both administratively and academically. For this reason, a mechanism that is able to organize the stages of activities and the involvement of various parties that are directly or indirectly related to this activity is needed. An overview of the stages of activities and parties' involvement in fostering student character can be seen in the following table:

Table 2 Portfolio Development Mechanisms

\begin{tabular}{|c|c|c|c|c|}
\hline \multirow{2}{*}{ No. } & \multirow{2}{*}{ Activity Stages } & \multicolumn{3}{|c|}{ Involvement } \\
\hline & & Department & Lecturer & Student \\
\hline 1. & Socialization & q & & \\
\hline 2. & Making Commitment & L & 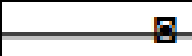 & a \\
\hline 3. & Action & $\Gamma$ & E & 常 \\
\hline 4. & Monitoring & 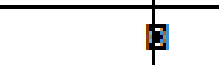 & & \\
\hline 5. & Reporting & & 9 & d \\
\hline 6. & Recapitulation & 直 & 耳 & \\
\hline 7. & Revision and development & a- & $-\frac{1}{6}$ & \\
\hline
\end{tabular}

Stages of activities and involvement of parties related to student character development certainly do not necessarily become part that is responsible alone or unilaterally, but instead becomes a part of the whole system with one another. This means that between one stage to another stage, it is well developed and coordinated between the parties involved with each other, making a character development a good system.

\section{Basis for Developing Student Character Development Portfolios}

The basis for developing student character education portfolios is based on the things that have a religious, institutional, and human foundation. The basis is as follows: 
Mardianto, Irwan S, Fauziah Nasution / JURNAL TARBIYAH 26 (2) (2019) 237-262

\section{Normative}

The normative basis is the basic religious values sought, discovered and established as a reference in developing character education for students. In this case the normative basis is based on the Qur'an and Al-Hadith. Al Quran Surah Al Baqarah verse 286 (QS, 2: 286) explains that: Allah does not burden a person, but according to his ability. He gets the reward (from virtue) that he works for and he gets the torture (from evil) that he does. (They pray): "Our Lord! Punish us not if we forget or fall into error, our Lord! Lay not on us a burden like that which You did lay on those before us (Jews and Christians); our Lord! Put not on us a burden greater than we have strength to bear. Ardon $\mathrm{u}$ and grant us Forgiveness. Have mercy on us. You are our Maula (Patron, Supporter, Protector, etc.) ad give us victory over the disbelieving people." Al Hadith History (HR) Muslim explains that: You do not have faith, so that you love your brother as you love yourself. Towards kindness is full of challenges, but working continuously is better.

\section{Rational}

The duration of study for undergraduate students is four to six years, for that student coaching can be done periodically but continuously for seven semesters. Educational activities carried out regularly will have an impact on coaching, mentoring, and control of their development within a certain period of time.

\section{UIN of North Sumatra Medan the Champion}

North Sumatra State Islamic University Medan has a vision and mission as well as goals as higher education institutions. As an Islamic educational institution, as a state educational institution in Indonesia, as an educational institution, it has a duty; education, research and giving to the community. For this reason, including the involvement of all components of higher education is a strategy to achieve the vision and mission and objectives of UIN of North Sumatra Medan to become a Champion (Advanced and Prosperous). The value obtained from character education certainly starts from changes in students, then becomes the success of the departments, as well as an institution in this case UIN of North Sumatra Medan which became the Champion. Three values that obtain benefits are; personal character, professional character, and the character of the community.

4. Build personal character

Students are a status that is shared by a group of generations who are attending higher education. Participating in learning requires sincere intention, strong will, and good self-control. These activities must always be managed properly, whether by 
themselves, in groups, interacting with various opportunities and so on. The values of character that are born from this personal character are; dawn prayers in congregation in the mosque, tahajjud prayer, duha prayer, rawatib prayer, fasting, prayer in 100 mosques, and ifnaq (alms).

5. Building professional character

Reading and memorizing the Qur'an, praying and communicating with parents, The values of characters born from this character are; has a standard email, blog, google drive, active in religious social organizations, teaches at madrasas and teaches privacy.

6. Build character

Systems thinking is an academic skill, how a student places himself is part of the department, part of the faculty, and part of the institution in this case UIN of North Sumatra Medan. And finally UIN of North Sumatra Medan is part of the Ummah (community) on this earth. The values developed from the character of this community are; writing in journals, in other mass media and making books.

From the above development, the students' character is done by creating a portfolio on 17 character values. The seventeen characters are classified into good practice personal practice, professional practice, and finally is the practice for the Ummah. The development table of 17 character values can be seen in the following table:

Table 3 Development Form 17 Character Values

\begin{tabular}{|c|c|c|c|c|}
\hline \multirow[t]{2}{*}{ No. } & \multirow[t]{2}{*}{ Personal Activities/Building Character } & \multicolumn{3}{|c|}{ Practice } \\
\hline & & $\mathbf{P}$ & $\mathbf{P r}$ & $\mathbf{C}$ \\
\hline 1 & Shubuh Prayer together in Masjid (Islamic worship place) & 0 & & $\nabla$ \\
\hline 2 & Reciting/memorizing Al Qur'an & 0 & & \\
\hline 3 & Pray/communicating with mother/father & D & & \\
\hline 4 & Tahajjud prayer & Q & & \\
\hline 5 & Dhuha prayer & Q & & \\
\hline 6 & Rawatib prayer & 口 & & \\
\hline 7 & 1213 fasting (Monday and Thursday) & a & & \\
\hline 8 & Prayer in 70 Masjid & Q & & $\square$ \\
\hline 9 & Infaq 7 times in sequence & Q & & $\nabla$ \\
\hline 10 & E-mail and standard blog & & 口 & \\
\hline 11 & Google drive & & Q & \\
\hline
\end{tabular}


Mardianto, Irwan S, Fauziah Nasution / JURNAL TARBIYAH 26 (2) (2019) 237-262

\begin{tabular}{|l|l|c|c|c|}
\hline 12 & Joining a social / religious organization & & $\square$ & $\square$ \\
\hline 13 & Serving one of the department objectives & & $\square$ & $\square$ \\
\hline 14 & Building a community & & $\square$ & \\
\hline 15 & Writing in the journal & & $\square$ & $\mathbf{0}$ \\
\hline 16 & Writing in mass media & & $\square$ & $\square$ \\
\hline 17 & Publishing book & & $\square$ & $\mathbf{0}$ \\
\hline
\end{tabular}

\section{Gloss:}

$\mathrm{P} \quad=$ Personal (specifically for personal practices)

Pr $\quad=$ Profession (practices which support profession)

$\mathrm{C} \quad=$ Community (practices which build the community)

From developing these values, the researcher then develops the duration or time that must be taken when the student will fulfill or carry out his activities. This development is certainly based on the time ratio taken by students, especially for one semester of study or one strata one department for eight semesters. Then explained in the form of an explanation of each portfolio to be a guide for student implementation, the results are as follows:

Table 4 Form Explanation of Character Building Activities

\begin{tabular}{|l|l|l|l|l|l|}
\hline \multirow{2}{*}{ No } & \multicolumn{1}{|c|}{$\begin{array}{c}\text { Personal Activities/Building } \\
\text { Character }\end{array}$} & \multicolumn{2}{|c|}{ Practice } & \multirow{2}{*}{ Explanation } \\
\cline { 4 - 5 } & \multicolumn{1}{|c|}{$\begin{array}{l}\text { O } \\
\text { HR }\end{array}$} & R & \\
\hline $\mathbf{1}$ & $\begin{array}{l}\text { Shubuh Prayer together in Masjid (Islamic } \\
\text { worship place) }\end{array}$ & & & & $\begin{array}{l}\text { Special for male } \\
\text { student }\end{array}$ \\
\hline 3 & Reciting/memorizing Al Qur'an & & & & Last 24 hours \\
\hline 3 & Pray/communicating with mother/father & & & & Last 24 hours \\
\hline 4 & Tahajjud prayer & & & & - \\
\hline 5 & Dhuha prayer & & & & \\
\hline 6 & Rawatib prayer & & & & - \\
\hline 7 & 1213 fasting (Monday and Thursday) & & & & $\begin{array}{l}7 \text { times in } \\
\text { sequence (male } \\
\text { sudent) }\end{array}$ \\
\hline
\end{tabular}


Mardianto, Irwan S, Fauziah Nasution / JURNAL TARBIYAH 26 (2) (2019) 237-262

\begin{tabular}{|l|l|l|l|l|l|}
\hline 8 & Prayer in 70 Masjid & & & & $\begin{array}{l}\text { Preferred (male } \\
\text { student) }\end{array}$ \\
\hline 9 & Infaq 7 times in sequence & & & & - \\
\hline 10 & E-mail and standard blog & & & & Second meeting \\
\hline 11 & Google drive & & & & Third meeting \\
\hline 12 & Joining a social / religious organization & & & $\begin{array}{l}\text { During one } \\
\text { semester }\end{array}$ \\
\hline 13 & Serving one of the department objectives & & & $\begin{array}{l}\text { During one } \\
\text { semester }\end{array}$ \\
\hline 14 & Building a community & & & $\begin{array}{l}\text { At least 3 } \\
\text { students }\end{array}$ \\
\hline 15 & Writing in the journal & & & $\begin{array}{l}\text { Within one } \\
\text { semester }\end{array}$ \\
\hline 16 & Writing in mass media & & & & \\
\hline 17 & Publishing book & & & & \\
\hline
\end{tabular}

Gloss: $O=$ Obligatory, $H R=$ Highly Recommended, $R=$ Recommend

Each student is burdened with a portfolio of qualifications $\mathrm{W}$ which is required by an individual student, because the values developed in this case are based on knowledge, experience, individual obligations both in Islam, in academic activities and in everyday life. While Highly Recommended are the values that are based on the high likelihood for students to do because of their abilities, time, and opportunities to do it either alone or together. And finally, this is a suggestion, meaning students are given a suggestion to do the character value activities will be part of a good character.

From the explanation above, then it is stated in quantitative form, the intention is to make a measurement that can be made a checklist for lecturers and students, whether the value has been done or not. This quantitative value is considered important to be a reference to the meaning of characters that are built and developed.

\section{Guidelines for Interpretation and Recommendations}

Finally, a program that can be developed to measure whether the portfolio assessment can be fulfilled by students or not, then the measure is assessed quantitatively for one semester and given meaning to the levels as described below: 
Table 5 Guidelines for Scoring Character Coaching

\begin{tabular}{|c|c|c|c|c|c|c|c|}
\hline \multicolumn{8}{|c|}{ Identity } \\
\hline $\mathbf{1}$ & Name & \multicolumn{6}{|l|}{$\mathrm{XXX}$} \\
\hline 2 & Students ID & \multicolumn{6}{|l|}{$\mathrm{XXX}$} \\
\hline 3 & Sem/Dep & \multicolumn{6}{|l|}{ XXX } \\
\hline 4 & Academic Year & \multicolumn{6}{|l|}{$\mathrm{XXX}$} \\
\hline 5 & e-mail & \multicolumn{6}{|l|}{$\mathrm{XXX}$} \\
\hline No & \multicolumn{2}{|c|}{ Personal Activities/Character Building } & \multicolumn{5}{|c|}{ Score } \\
\hline 1 & \multicolumn{2}{|c|}{$\begin{array}{l}\text { Shubuh Prayer together in Masjid (Islamic } \\
\text { worship place) }\end{array}$} & 20 & 40 & 60 & 80 & 100 \\
\hline 2 & \multicolumn{2}{|c|}{ Reciting/memorizing Al Qur'an } & 20 & 40 & 60 & 80 & 100 \\
\hline 3 & \multicolumn{2}{|c|}{ Pray/communicating with mother/father } & 20 & 40 & 60 & 80 & 100 \\
\hline 4 & \multicolumn{2}{|l|}{ Tahajjud prayer } & 20 & 40 & 60 & 80 & 100 \\
\hline 5 & \multicolumn{2}{|l|}{ Dhuha prayer } & 20 & 40 & 60 & 80 & 100 \\
\hline 6 & \multicolumn{2}{|l|}{ Rawatib prayer } & 20 & 40 & 60 & 80 & 100 \\
\hline 7 & \multicolumn{2}{|c|}{1213 fasting (Monday and Thursday) } & 20 & 40 & 60 & 80 & 100 \\
\hline 8 & \multicolumn{2}{|l|}{ Prayer in 70 Masjid } & 20 & 40 & 60 & 80 & 100 \\
\hline 9 & \multicolumn{2}{|c|}{ Infaq 7 times in sequence } & 20 & 40 & 60 & 80 & 100 \\
\hline 10 & \multicolumn{2}{|c|}{ E-mail and standard blog } & 20 & 40 & 60 & 80 & 100 \\
\hline 11 & \multicolumn{2}{|l|}{ Google drive } & 20 & 40 & 60 & 80 & 100 \\
\hline 12 & \multicolumn{2}{|c|}{ Joining a social / religious organization } & 20 & 40 & 60 & 80 & 100 \\
\hline 13 & \multicolumn{2}{|c|}{ Serving one of the department objectives } & 20 & 40 & 60 & 80 & 100 \\
\hline 14 & \multicolumn{2}{|c|}{ Building a community } & 20 & 40 & 60 & 80 & 100 \\
\hline 15 & \multicolumn{2}{|c|}{ Writing in the journal } & 20 & 40 & 60 & 80 & 100 \\
\hline 16 & \multicolumn{2}{|c|}{ Writing in mass media } & 20 & 40 & 60 & 80 & 100 \\
\hline 17 & \multicolumn{2}{|l|}{ Publishing book } & 20 & 40 & 60 & 80 & 100 \\
\hline & \multicolumn{2}{|l|}{ Total Column } & & & & & \\
\hline & \multicolumn{5}{|c|}{ Total Score } & & \\
\hline
\end{tabular}

Gloss: $O=$ Obligatory, $H R=$ Highly Recommended, $R=$ Recommend

\begin{tabular}{|l|c|c|c|c|}
\hline Rank & I & II & III & IV \\
\hline Total Score & $340-680$ & $680-1020$ & $1020-1360$ & $1360-1700$ \\
\hline Rank & Good & Futuristic & Superior & Champion \\
\hline
\end{tabular}


And the description of levels I, II, III and IV as well as the level of student results, can be seen as described below:

\section{Good Character}

1. This student is newly able to have good character. From the things done so far there have not been many positive things related to daily life that have contributed to personal progress, the Ummah especially supports the profession.

2. Assistance that must be done is to provide reinforcement to Academic Advisory lecturers, will provide a schedule strict guidance to meet the policy targets for the following semester.

\section{Futuristic}

1. This student is futuristic, in which he has just started religious activities both incidentally and continuously.

2. Coaching that needs to be done is academic advisors to collaborate with student activities and the department to provide opportunities for students to engage in positive matters.

\section{Superior Character}

1. This student is already having a superior character by collecting several points related to religious life in private, as well as society. The values possessed indicate the existence of goodness that has not been maximally made possible because time has not been well ordered.

2. Control that should be done is to continue to provide direction and control so that activities do not stop at certain parts, but continue to be a routine in daily life both individually and in groups.

\section{Champion Character}

1. This student is gaining championship ability. The points obtained indicate indicators that students are accustomed to a good religious life, have qualified academic skills, and are able to utilize time perfectly.

2. Appreciation is appropriate given by giving confidence to them to be part or even a leader in the student activity unit within UIN of North Sumatra Medan. 


\section{Research Limitations}

This research has various reasons to explain that design development as a model needs to be further developed. The three main parties that must be used as a coordinating line as the model developed are:

1. The curriculum quality Assurance Institute in the environment of UIN of North Sumatra Medan. During this time the organizational structure contained in the Quality Assurance Sheet is the Chairperson, secretary, with three central heads, namely; center for developing quality standards, center for auditing and quality control, as well as center for mentoring and developing student quality. Until this research it was reported that the LPM would develop a special field or body that would manage the curriculum and this would be included in the upcoming statute change of the UIN of North Sumatra Medan.

2. The Vice Rector I, and the Vice Rector III where the two leaders are those who have the authority to increase, develop and develop and control the character of students.

3. The Student Disciplinary Commission formed by the Chancellor of UIN North Sumatra. We are not able to coordinate well with this party, where in the next research it is expected that the development of student character is part of an effort to improve the function and role of the Student Disciplinary commission in UIN of North Sumatra Medan environment.

\section{CONCLUSION AND RECOMMENDATION}

\section{Conclusions}

This study found that to develop the character education design through an integrated curriculum in learning activities at UIN North Sumatra Medan, one design was formulated in a model. The design model of character education development will be effective if done with three things, namely; integrated curriculum development, coordination between institutions, and commitment of organizers or related parties.

Curriculum development can be done with improvement, and development at the level of LPM UIN of North Sumatra Medan. This development can be done by making manuals, manuals, and technical manuals on the implementation of character education that is integrated in the curriculum of UIN of North Sumatra Medan. Vice Chancellor for Student Affairs, Alumni and Cooperation and also Vice Dean for Academic and Institutional Affairs, and Deputy Dean for Student Affairs, Alumni and Cooperation and Academic advisors in fostering student character. Organizational commitment can be 
Mardianto, Irwan S, Fauziah Nasution / JURNAL TARBIYAH 26 (2) (2019) 237-262

pursued by providing space for Academic advisors to understand, develop and evaluate how the implementation of character education for students.

\section{Recommendations}

The results of this study recommend directly for curriculum development activities and learning at UIN North Sumatra Medan. The parties related to learning are LPM, lecturers, students, and curriculum developers. Specifically the contribution of this study recommends the following parties: (1) To the LPM to be able to develop curriculum that can integrate character education in all handbooks, manuals, technical manuals related to education, learning in the UIN of North Sumatra Medan environment. (2) To the faculties, especially the Department in order to provide media or space for lecturers and students to equalize perceptions about character development in learning activities. (3) To the Academic advisor, in order to be able to learn, develop, and implement character education at the meeting activities among at the beginning, at the core activities and on the evaluation system that is developed.

\section{REFERENCES}

Abdullah Nashih Ulwan, Pedoman Pendidikan Anak dalam Islam, Semarang: Asy Syifa, 1981.

Abdul Majid dan Dian Andayani, Pendidikan Karakter Perspektif Islam, Bandung: Remaja Rosdakarya, 2017.

Abdul Mukhid, Konsep Pendidikan Karakter dalam Al Qur`an, Jurnal Nuansa, Vol. 13 No. 2 Juli - Desember 2016

Amini, Pengembangan Model Pendidikan Karakter melalui Kurikulum Terintegrasi pada Tingkat Pendidikan Dasar di Kota Medan, Dikti: Laporan Penelitian Hibah Bersaing, 2016.

Astuti Irene, Pendekatan Holistik dan Kontekstual dalam Mengatasi Krisis Krakter di Indonesia, dalam Cakrawala Pendidikan (Yogyakarta: UNY, Mei 2010 Tahun XXIX, Edisi Khusus Dies Natalis UNY).

Atwi Suparman, Desain Instruksional, Jakarta: Dirjen Dikti, 1987

Dewi Prasari Suryawati, Implementasi Pembelajaran Aqidah Akhlak terhadap

Pembentukan Karakter Siswa di MTs Negeri Semanu Gudung Kidul, Yogyakarta: 2016. 
Mardianto, Irwan S, Fauziah Nasution / JURNAL TARBIYAH 26 (2) (2019) 237-262

Dian Kurniati, Pengembangan Perangkat Pembelajaran Matematika SMP dengan

Sistem Character Based Integrated Learning, Kreano.Vol.4 No.2 Tahun 2013 Elizabet E.Barkley, K.Patricia Cross dan Claire H.Major, Collaborative Learning

Techniques, Bandung: Nusa Media, 2012. (terj. Narulita Yusron).

E.Mulyasa, Manajemen Pendidikan Karakter, Jakarta: Bumi Aksara, 2014.

Imam Al Nawawi, Etika Interaksi Antara Dosen dan Mahasiswa, Medan: IAIN Press, 2011. (terj.Tim Zawiyah Kutb at Turast).

James C.Sarros, Leadership and Character, Monash University, (C) Emerald Group

\section{Publishing Limited2006}

Jamilah, Pengintegrasian Character Builiding pada Mata Kuliah Pronunciation

Melalui Project-Based Learning, Jurnal Pendidikan Karakter, Tahun V, Nomor 1, April 2015

Jerorld E.Kemp, The Instructional Design Process, New York: Harper \& Row, 1985.

John Sigal, Shirley Braverman, Robert Pilon \& Patrick Baker, Effects of Teacher-Led,

Curriculum-Integrated Sensitivity Training in a Large High School 1, The Journal of Eductional Research, 2014

Kementerian Pendidikan Nasional RI BPPK, Pengembangan Pendidikan Budaya dan Karakter Bangsa: Pedoman Sekolah, Jakarta, 2010

M. David Marrill, Second Generation Instructional Design

Available,http://www.id2.usu.edu/id2/index.htm.

Marzuki, Pendidikan Karakter, Jakarta: Amzah, 2017.

Norayeni Arista Estuwardani dan Ali Mustadi, Pengembangan Bahan Ajar Modul

Tematik- Integratif dalam Peningkatan krakter Peserta didik Kelas I Sekolah Dasar, Jurnal Pendidikan Karakter, Tahun V, Nomor 2, Oktober 2015

Raigeluth, Charles M, (ed), Instructional-Design Theories and Models: An Overview

of Their Current Status, New Jersey Lowerence Erlbaum Associates, 1983.

Ruseno Arjanggi, Pendidikan Karakter Terintegrasi dalam Pembelajaran di Perguruan

Tinggi, https://www.researchgate.net/publication/28141665,2012

Sutarjo Adisusilo JR, Pembelajaran Nilai-nilai Karakter: Konstruktivisme dan VCT

sebagai Inovasi Pendekatan Pembelajaran Afektif, Jakarta: Rajawali, 2014.

Syaiful Sagala, Etika \& Moral Pendidikan: Peluang dan Tantangan, Jakarta:

Kencana, 2013.Thomasm Lickona, Character Matters Persoalan Karakter:

Bagaimana membantu Anak Mengembangkan Penilaian Yang Baik, Integritas, dan Kebajikan Penting Lainnya, Jakarta: Bumi Aksara, 2016, (terj.Juma \&Jien) 
Mardianto, Irwan S, Fauziah Nasution / JURNAL TARBIYAH 26 (2) (2019) 237-262

Trianto Ibnu Bada al Tabany, Mendesain Model Pembelajaran Inovatif, Progresif dan Kontekstual, Jakarta: Kencana, 2014.

UIN Sumatera Utara Medan, Buku Panduan Akademik UIN SU Tahun 2016/2017.

UIN Sumatera Utara Medan, Statuta Universitas Islam Negeri Sumatera Utara Medan Tahun 2016, Medan, 2016.

Undang Undang RI No.20 Tahun 2003 Tentang Sistem Pendidikan

Nasional. Undang Undang RI No.14 Tahun 2005 Tentang Guru dan

Dosen.

Yuni Novitasari dan Eko Susanto, Pendidikan Karakter Bagi Mahasiswa di Perguruan Tinggi Dalam Rangka Menghadapi Era Globalisasi, 2016.

Zubaedi, Desain Pendidikan Karakter: Konsepsi dan Aplikasi dalam lembaga Pendidikan, Jakarta: Kencana, 2011. 